
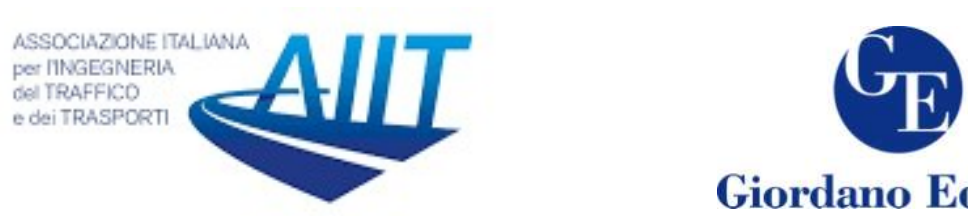

Giordano Editore

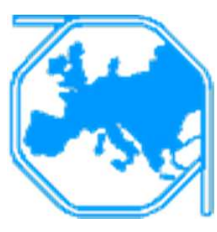

\title{
Statistical Evaluation of Risky Driver Behavior Factors that Influence Road Safety based on Drivers Age and Driving Experience in Budapest and Islamabad
}

\author{
Danish Farooq ${ }^{1 *}$, Janos Juhasz ${ }^{2}$ \\ ${ }^{I}$ Department of Transport Technology and Economics, Budapest University of Technology and \\ Economics \\ ${ }^{2}$ Associate Professor, Department of Transport Technology and Economics, Budapest University of \\ Technology and Economics
}

\begin{abstract}
Driver behavior is considered as one of the most influential factors on road safety. Most of the drivers on road involve in risky driving attitudes which cause fatal and seriously injured road accidents. This study aims to evaluate and compare the risky driver behavior factors that influence road safety based on drivers age and driving experience for Budapest and Islamabad. To achieve this, the study utilized the well-proved driver behavior questionnaire (DBQ) designed on a three-point scale to analyse statistically the driver behavior responses on perceived road safety issues. The study overall results found that drivers with age group '18-21 year' and drivers with driving experience less than one year are more likely to involve in risky driver behavior factors as compared to other studied groups. Furthermore, the Budapest drivers with age group '18-21 year' and driving experience less than one year are more concerned in risky driver behavior factors such as 'disregard speed limit', 'failing to use personal intelligent assistant' and 'frequently changing lanes'. While Islamabad drivers with the same demographic characteristics are more concerned in several risky driver behavior factors as compared to other age and driving experience groups. Moreover, ANOVA analysis was run to measure the statistical significance of risky driver behavior factors between designated groups of drivers. Finally, relative risk (RR) was measured to compare that how much times one driver group is more likely to involve in risky driver behavior factors as compared to the other driver group in the sample. The study highlighted the most frequent risky driver behavior factors for each observed group to help the local policymakers to solve related road safety issues.
\end{abstract}

Keywords: Risky driver behavior, driver behavior questionnaire, drivers age, driving experience, ANOVA, road safety

\section{Introduction}

On the world's roads, over 1.35 million people lose their lives each year, and as many as 50 million are injured (WHO, 2020). Human factors have been estimated to be a sole or leading causal factor in approximately $90 \%$ of road accidents (NHTSA, 2008; Papaioannou, 2007). The situation analysis of the 'Road Safety Action Program' observes

\footnotetext{
* Corresponding author: Danish Farooq (farooq.danish@mail.bme.hu)
} 
that most of the accidents are caused by human issues. Therefore, influencing them become the most essential target of road safety actions (OECD/ITF, 2016).

Previous study noticed that the age of the driver is a significant factor in accident involvement (Bener et al., 2008). The young driver characteristic of normlessness is common for individuals during adolescence and thus leading them to have more antisocial attitudes and behaviors (Machin and Sankey, 2008). Road traffic crashes are the main cause of death among those aged 15-29 year (WHO, 2013). In Australia in 2013, young drivers with age group ' $17-25$ year' contributed $21.3 \%$ of the fatally-injured drivers (BITRE, 2014). Also, the IRTAD annual report stated that '17-25 age-group' has the highest rate of fatalities per population (IRTAD-OECD, 2011). A report declared a high number of road fatalities by young driver age groups in various countries as shown in Figure 1.

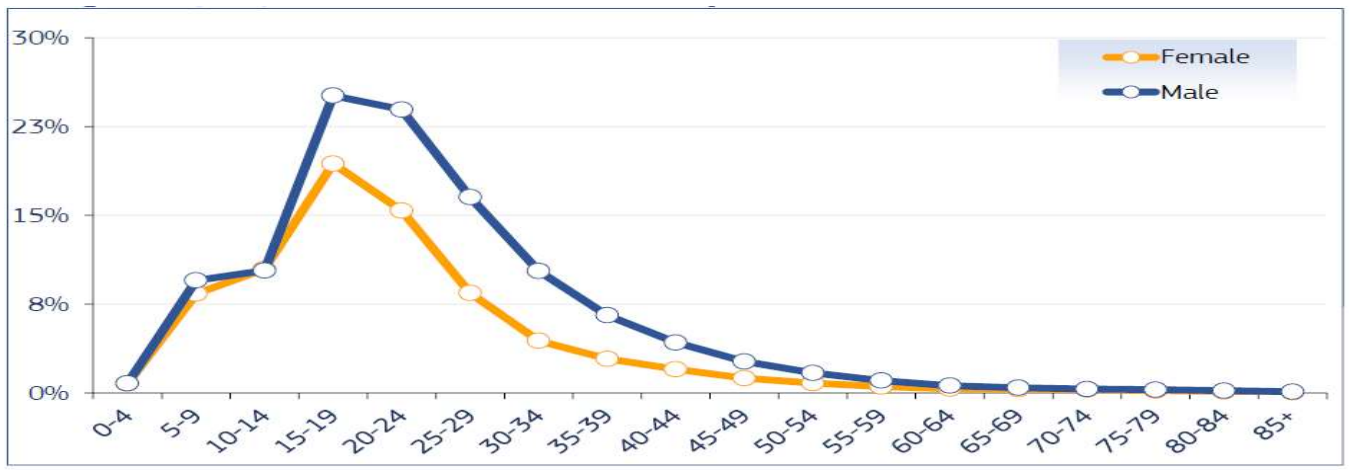

Figure 1: Percentage of road accident fatalities of all fatalities by age group and gender (EU Commission, CARE database, 2016)

Regardless of age, inexperienced drivers notice traffic hazards more slowly, less holistically and less proficiently than experienced drivers do, and underestimate the traffic crash risk (Machin and Sankey, 2008). Adolescent's drivers inexperience and their involvement in risky behavior and low-risk perception were found associated with the high number of teenage traffic crashes and deaths (Salvatore et al., 2019).

The cultural differences were previously studied in risk perception and approach towards traffic safety and risk-taking behavior in different regions (Lund and Rundmo, 2009). There are generally significant differences found in driving practice and their traffic risk perception between countries (Ozkan et al., 2006). The findings of the previous studies have revealed that self-reported driving behaviors are related with both active and passive traffic accidents among drivers with different demographic characteristics within a range of cross-cultural populations (Al Reesi et al., 2013). To deal with this problem effectively, a better understanding of the young driver behavior and its factors is needed (Prato et al., 2010).

This study aims to evaluate and compare the risky driver behavior factors based on drivers age and driving experience for Budapest and Islamabad. The previous study (Farooq and Juhasz, 2018) utilized the designated driver behavior questionnaire (DBQ) to analyse the differences in risky driver behavior factors between two specified regions. While this study utilized further the same driver behavior questionnaire (DBQ) to measure the differences in driver's responses based on age and driving experience. Furthermore, ANOVA analysis was performed to measure the statistical significance of risky driver behavior factors for evaluator groups. Finally, the relative risk was measured 
to compare the likelihood of one driver group involves in DBQ items as compared to other studied group.

\section{Methodology}

\subsection{DBQ survey and study area}

The Driver Behavior Questionnaire (DBQ) is one of the most commonly used tools for estimating driving behavior towards road safety. To evaluate deviant driving behavior, the Driver Behavior Questionnaire (DBQ) was first utilized as a tool in the related studies 1990s (Parker et al., 1995; Reason et al., 1990). The DBQ survey in this study was designed into two parts with the range of information: The first part aimed to collect the demographic data of participants as shown in Table 1. The DBQ data was collected from university students of Budapest and Islamabad with sample size $(\mathrm{N}=140)$ of participants by considering equal participation of both age groups (18-21 year, 22-25 year) and driving experience groups $(<1$ year, $\geq 1$ year) for analysis purposes. The results presented the mean and standard deviation (SD) values of observed characteristics based on drivers' responses to describe the specified driver's characteristic.

Accordingly, the second part of DBQ aimed to evaluate and compare the eleven risky driver behavior factors that influence road safety significantly (Farooq et al., 2019; Farooq and Sarbast, 2019). To collect DBQ data on a three-point scale (often, sometimes, never), the participants in Budapest were approached and asked to fill the DBQ on perceived road safety issues. While the DBQ data was collected from Islamabad participants with the help of research assistants.

Table 1: Sample characteristics

\begin{tabular}{llll}
\hline \multicolumn{1}{c}{ Variables } & Statistic terms & $\begin{array}{l}\text { Budapest } \\
\mathrm{N}=140\end{array}$ & $\begin{array}{l}\text { Islamabad } \\
\mathrm{N}=140\end{array}$ \\
\hline Age & & 22.456 & 23.605 \\
& Mean & 3.153 & 4.879 \\
Gender & $\mathrm{SD}$ & & \\
Male & & 113 & 109 \\
Female & Numbers & 27 & 31 \\
Driving Experience & & 2.236 & 3.126 \\
& Mean & 1.875 & 2.156 \\
\hline
\end{tabular}

\subsection{Risky driver behavior factors}

Risky driving behaviors are the leading cause of traffic crashes which signify a main public safety concern (Iversen, 2004). The DBQ questionnaire consists of 11 items of risky driving attitudes designed on closed questions, that is, multiple choices on a threepoint scale ( $1=$ often, $2=$ sometimes, $3=$ never) for the convenience of statistical analysis. Participants were asked to indicate how often they involve in risky attitudes while driving in recent one year. The eleven-examined driver behavior questionnaire (DBQ) items with designated symbols and their importance for road safety have been shown in Table 2 . 
Table 2: A summary of studies on risky driver behavior factors affecting road safety

\begin{tabular}{|c|c|c|}
\hline Authors & Risky Driver Behavior Factors & Main Findings \\
\hline $\begin{array}{l}\text { Subramaniam et al., } \\
2007\end{array}$ & $\begin{array}{l}\text { Failing to comply with traffic } \\
\text { light signal (Q1) }\end{array}$ & $\begin{array}{l}\text { One of the possible causes for the high number } \\
\text { of crashes and injuries is due to beating traffic } \\
\text { lights. }\end{array}$ \\
\hline $\begin{array}{l}\text { Bilban and Zaletel- } \\
\text { Kragelj, } 2007\end{array}$ & Failing to wear seat belt (Q2) & $\begin{array}{l}\text { The probability of deaths in car accidents is } \\
2.34 \text { times higher for the drivers who do not } \\
\text { wear the seatbelt than for those who wear it. }\end{array}$ \\
\hline Hassan et al., 2017 & Disregard speed limit (Q3) & $\begin{array}{l}\text { Speeding is one of the serious and most } \\
\text { common aberrant driving behaviors that } \\
\text { negatively affect the safety of the violators } \\
\text { themselves and the whole motorized } \\
\text { community. }\end{array}$ \\
\hline $\begin{array}{l}\text { Gholamreza Khorasani } \\
\text { et al., } 2013\end{array}$ & $\begin{array}{l}\text { Failing to use personal intelligent } \\
\text { assistant (Q4) }\end{array}$ & $\begin{array}{l}\text { Intelligent Transport Systems (ITS), based on } \\
\text { advanced telecommunication and information } \\
\text { technology, offer a great potential for } \\
\text { improving the road safety situation for all } \\
\text { types of road-users. }\end{array}$ \\
\hline Viola et al., 2010 & Failing to yield pedestrian (Q5) & $\begin{array}{l}\text { Failure to yield at pedestrian crossings is one } \\
\text { of the riskiest factors that contribute to } \\
\text { pedestrian injury. }\end{array}$ \\
\hline $\begin{array}{l}\text { Rachel Talbot et al., } \\
2016\end{array}$ & Driving too closely (Q6) & $\begin{array}{l}\text { Following too closely is seen as one of the } \\
\text { main reasons for rear end crashes. }\end{array}$ \\
\hline Wang et al., 2016 & Frequently changing lanes (Q7) & $\begin{array}{l}\text { Frequent lane-changing have an adverse effect } \\
\text { on traffic efficiency under advanced traffic } \\
\text { demand. }\end{array}$ \\
\hline ADB, 1996 & Risk due to encroachments (Q8) & $\begin{array}{l}\text { Many problems associated with street vendors } \\
\text { and encroachment which affect road safety in } \\
\text { the particular conditions that apply in that } \\
\text { country. }\end{array}$ \\
\hline $\begin{array}{l}\text { Yanagisawa et } \\
\text { al., } 2014\end{array}$ & Failing to apply brakes (Q9) & $\begin{array}{l}\text { More fatalities can occur if the driver does not } \\
\text { apply the brakes and has higher impact-speed } \\
\text { crashes with the pedestrian. }\end{array}$ \\
\hline Chakraborty, 2014 & Problems of mixed traffic (Q10) & $\begin{array}{l}\text { Mixed traffic leads vehicles not to follow } \\
\text { strict lane discipline and occupy any available } \\
\text { space on the road. The interactions among } \\
\text { vehicles and the resulting maneuvers they } \\
\text { undertake are much more complex in mixed } \\
\text { traffic conditions. }\end{array}$ \\
\hline Takada et al., 2010 & Sounds horn in annoyance (Q11) & $\begin{array}{l}\text { The previous psychoacoustic study } \\
\text { investigating the effects of horn sounds on } \\
\text { auditory impressions in both the driving and } \\
\text { pedestrian conditions suggested its negative } \\
\text { effects, particularly on pedestrians. }\end{array}$ \\
\hline
\end{tabular}

\subsection{ANOVA analysis}

Analysis of variance (ANOVA) is a combination of statistical models and their related measures used to analyse the differences between two or more means of independent 
variables (Park et al., 2009). The previous study employed the ANOVA approach to measure the significant differences between countries based on DBQ items and scale scores (Lord et al., 2005). The ANOVA analysis contains significant information about the model measures which are discussed here: Firstly, total Degree of Freedom (DF) shows how much information the model data use. This is calculated by subtracting digit one from the total number of values in an independent variable source. Furthermore, the Mean Square (MS) value describes that how much a term or model explains the variation, assuming that all other elements are in the model, regardless of the order they were used. This is evaluated by dividing the sum of square values by degree of freedom. Subsequently, F-value is used to estimate whether the factor is related to the response variable or not. While F-statistic (also known as F-critical value) is computed from the data and represents how much the variability among the means exceeds that expected due to chance. F statistics is calculated by dividing the variance of the group means by mean of the within group variable. The F statistic must be utilized in combination with the pvalue while deciding if overall results are significant. Accordingly, P-value is utilized to measure the significance of DBQ items. The p-value is a probability that decides the evidence against the null hypothesis (Farooq and Juhasz, 2018).

\subsection{Relative risk}

Relative Risk (RR) is often used when the study implies comparing the likelihood, or risk, of an event occurring between two groups. Relative Risk is usually calculated by dividing the probability of an event occurring for group one divided by the probability of an event occurring for the other group. A value of 1 presents a neutral result: the chance of an event occurring for one group is similar for an event occurring for the other group. A value greater than 1 shows the positive association which suggests an increased risk. However, a value of zero tells that none of the cases in group one had the event occur (Statistics Solutions, 2019).

\section{Results and discussion}

Descriptive statistics was applied to investigate the risky driver behavior factors based on DBQ data. The study analysis results showed that drivers with age group '18-21 year' and drivers with driving experience less than one year are more likely to involve in risky driver behavior factors as compared to other studied groups. In most countries, 18-20year old have the highest or second-highest traffic-related mortality of all age groups. Their risk to die in a road crash is typically twice as high as for the population average. The high crash rates of young drivers can be explained by high-risk behaviour, lack of experience and lifestyle associated with their age (OECD/ITF, 2018).

\subsection{Descriptive statistics}

\subsubsection{Budapest Sample}

For Budapest city, the drivers with age group '18-21 year' selected the option "often" with the high percentage $(\geq 20 \%)$ for driver behavior factors such as 'disregard speed limit' (25.7\%), 'failing to use personal intelligent assistant' $(22.9 \%)$ and 'frequently changing lanes' $(25.7 \%)$. The previous study also found that speeding is one of the serious and most common aberrant driving behaviors that negatively affect the safety of the 
violators themselves and the whole motorized community (Hassan et al., 2017). While the drivers with age group '22-25 year' selected the option "often" with the high percentage $(\geq 20 \%)$ only for one driver behavior factor such as 'failing to use personal intelligent assistant' $(28.6 \%)$. The previous study recommended that the Intelligent Transport Systems (ITS) based on advanced telecommunication and information technology offer great potential for improving the road safety situation for all types of road-users (Khorasani et al., 2013).

In case of driving experience, the drivers with driver experience less than one year $(<1$ year) selected the option "often" with high percentage $(\geq 20 \%)$ for driver behavior factors such as 'disregard speed limit' $(28.6 \%)$, 'failing to use personal intelligent assistant' $(25.7 \%)$ and 'frequently changing lanes' $(22.9 \%)$. While the drivers with driving experience equal to or greater than one year ( $\geq 1$ year) selected the option "often" with the high percentage ( $\geq 20 \%$ ) for two driver behavior factors such as 'failing to use personal intelligent assistant' (25.7\%) and 'frequently changing lanes' $(20 \%)$ as shown in Table 3.

Table 3: Descriptive analysis results for Budapest drivers

\begin{tabular}{|c|c|c|c|c|c|}
\hline \multirow[t]{2}{*}{ Driver behavior factors } & \multirow[t]{2}{*}{ Options } & \multicolumn{2}{|c|}{$\begin{array}{c}\text { Drivers Age } \\
\text { Frequency (\%) }\end{array}$} & \multicolumn{2}{|c|}{$\begin{array}{l}\text { Driving Experience } \\
\text { Frequency }(\%)\end{array}$} \\
\hline & & $\begin{array}{l}18-21 \text { year } \\
(\mathrm{N}=70)\end{array}$ & $\begin{array}{l}21-25 \text { year } \\
(\mathrm{N}=70)\end{array}$ & $\begin{array}{l}<1 \text { year } \\
(\mathrm{N}=70)\end{array}$ & $\begin{array}{l}\geq 1 \text { year } \\
(\mathrm{N}=70)\end{array}$ \\
\hline $\begin{array}{l}\text { Failing to comply with traffic } \\
\text { light signal (Q1) }\end{array}$ & $\begin{array}{l}\text { 1)Often } \\
\text { 2)Sometimes } \\
\text { 3)Never }\end{array}$ & $\begin{array}{l}4(5.7) \\
16(22.9) \\
50(71.4) \\
\end{array}$ & $\begin{array}{l}2(2.9) \\
8(11.4) \\
60(85.7) \\
\end{array}$ & $\begin{array}{l}6(8.6) \\
18(25.7) \\
46(65.7) \\
\end{array}$ & $\begin{array}{l}0(0) \\
6(8.6) \\
64(91.4)\end{array}$ \\
\hline Failing to wear seat belt (Q2) & $\begin{array}{l}\text { 1)Often } \\
\text { 2)Sometimes } \\
\text { 3)Never }\end{array}$ & $\begin{array}{l}3(4.3) \\
19(27.1) \\
48(68.6)\end{array}$ & $\begin{array}{l}4(5.7) \\
10(14.3) \\
56(80)\end{array}$ & $\begin{array}{l}2(2.9) \\
15(21.4) \\
53(75.7)\end{array}$ & $\begin{array}{l}5(7.1) \\
14(20) \\
51(72.9)\end{array}$ \\
\hline Disregard speed limit (Q3) & $\begin{array}{l}\text { 1)Often } \\
\text { 2)Sometimes } \\
\text { 3)Never }\end{array}$ & $\begin{array}{l}18(25.7) \\
48(68.6) \\
4(5.7)\end{array}$ & $\begin{array}{l}10(14.3) \\
40(57.1) \\
20(28.6) \\
\end{array}$ & $\begin{array}{l}20(28.6) \\
40(57.1) \\
10(14.3) \\
\end{array}$ & $\begin{array}{l}8(11.4) \\
48(68.6) \\
14(20)\end{array}$ \\
\hline $\begin{array}{l}\text { Failing to use personal intelligent } \\
\text { assistant (Q4) }\end{array}$ & $\begin{array}{l}\text { 1)Often } \\
\text { 2)Sometimes } \\
\text { 3)Never }\end{array}$ & $\begin{array}{l}16(22.9) \\
40(57.1) \\
14(20)\end{array}$ & $\begin{array}{l}20(28.6) \\
36(51.4) \\
14(20) \\
\end{array}$ & $\begin{array}{l}18(25.7) \\
44(62.9) \\
8(11.4) \\
\end{array}$ & $\begin{array}{l}18(25.7) \\
32(45.7) \\
20(28.6) \\
\end{array}$ \\
\hline Failing to yield pedestrian (Q5) & $\begin{array}{l}\text { 1)Often } \\
\text { 2)Sometimes } \\
\text { 3)Never }\end{array}$ & $\begin{array}{l}8(11.4) \\
22(31.4) \\
40(57.2)\end{array}$ & $\begin{array}{l}2(2.8) \\
6(8.6) \\
62(88.6)\end{array}$ & $\begin{array}{l}6(8.6) \\
18(25.7) \\
46(65.7)\end{array}$ & $\begin{array}{l}4(5.7) \\
10(14.3) \\
56(80)\end{array}$ \\
\hline Driving too closely (Q6) & $\begin{array}{l}\text { 1)Often } \\
\text { 2)Sometimes } \\
\text { 3)Never }\end{array}$ & $\begin{array}{l}5(7.1) \\
44(62.9) \\
21(30.0)\end{array}$ & $\begin{array}{l}4(5.7) \\
36(51.4) \\
30(42.9)\end{array}$ & $\begin{array}{l}8(11.4) \\
50(71.5) \\
12(17.1)\end{array}$ & $\begin{array}{l}3(4.3) \\
29(41.4) \\
38(54.3)\end{array}$ \\
\hline Frequently changing lanes (Q7) & $\begin{array}{l}\text { 1)Often } \\
\text { 2)Sometimes } \\
\text { 3)Never }\end{array}$ & $\begin{array}{l}18(25.7) \\
50(71.4) \\
2(2.9)\end{array}$ & $\begin{array}{l}12(17.1) \\
38(54.3) \\
20(28.6) \\
\end{array}$ & $\begin{array}{l}16(22.9) \\
46(65.7) \\
8(11.4)\end{array}$ & $\begin{array}{l}14(20) \\
42(60) \\
14(20)\end{array}$ \\
\hline Risk due to encroachments (Q8) & $\begin{array}{l}\text { 1)Often } \\
\text { 2)Sometimes } \\
\text { 3)Never }\end{array}$ & $\begin{array}{l}0(0) \\
18(25.7) \\
52(74.3)\end{array}$ & $\begin{array}{l}0(0) \\
12(17.1) \\
58(82.9)\end{array}$ & $\begin{array}{l}0(0) \\
10(14.3) \\
60(85.7)\end{array}$ & $\begin{array}{l}0(0) \\
20(28.6) \\
50(71.4)\end{array}$ \\
\hline $\begin{array}{l}\text { Failing to apply brakes in road } \\
\text { hazards (Q9) }\end{array}$ & $\begin{array}{l}\text { 1)Often } \\
\text { 2)Sometimes } \\
\text { 3)Never }\end{array}$ & $\begin{array}{l}0(0) \\
34(48.6) \\
36(51.4) \\
\end{array}$ & $\begin{array}{l}0(0) \\
16(22.9) \\
54(77.1) \\
\end{array}$ & $\begin{array}{l}0(0) \\
38(54.3) \\
32(45.7) \\
\end{array}$ & $\begin{array}{l}0(0) \\
12(17.1) \\
58(82.9) \\
\end{array}$ \\
\hline Problems of mixed traffic (Q10) & $\begin{array}{l}\text { 1)Often } \\
\text { 2)Sometimes } \\
\text { 3)Never }\end{array}$ & $\begin{array}{l}6(8.6) \\
26(37.1) \\
38(54.3)\end{array}$ & $\begin{array}{l}8(11.4) \\
32(45.7) \\
30(42.9)\end{array}$ & $\begin{array}{l}4(5.7) \\
22(31.4) \\
44(62.9)\end{array}$ & $\begin{array}{l}10(14.3) \\
36(51.4) \\
24(34.3)\end{array}$ \\
\hline
\end{tabular}




\begin{tabular}{|l|l|l|l|l|l|}
\hline Sounds horn in annoyance (Q11) & 1)Often & $11(15.7)$ & $4(5.7)$ & $12(17.2)$ & $2(2.9)$ \\
& 2)Sometimes & $32(45.7)$ & $16(22.9)$ & $37(52.8)$ & $12(17.1)$ \\
& 3)Never & $27(38.6)$ & $30(71.4)$ & $21(30.0)$ & $56(80)$ \\
\hline
\end{tabular}

For Budapest city, a comparison chart was first developed based on the driver's response "often" to compare between two age groups '18-21 year' and '22-25 year' as shown in Figure 2 (a). Results showed that drivers with age group '18-21 year' selected high the option "often" for most DBQ items as compared to drivers with age group '2225 year'. However, drivers with age group '22-25 year' selected high the option "often" for two DBQ items such as 'fail to use personal intelligent assistant' (Q4) and 'problems of mixed traffic' (Q10) as compared to age group '18-21 year'. Subsequently, a comparisons chart was developed to compare the percentage of option "often" between two driving experience groups ( $<1$ year and $\geq 1$ year) as shown in Figure 2 (b). Results showed that drivers having less than one year experience selected high the option "often" for most DBQ items as compared to drivers having driving experience equal to or greater than one year. The previous findings demonstrated that lack of driving experience was a stronger predictor of crash risk or near-crash events (McEvoy et al., 2006). However, drivers having driving experience equal to or greater than one year selected high the option "often" for two DBQ items such as 'failing to wear seat belt' (Q2) and 'problems of mixed traffic' (Q10) as compared to second observed group.

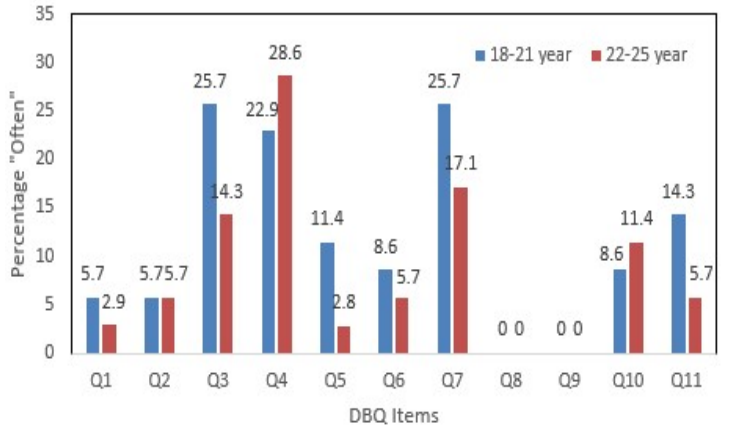

(a)

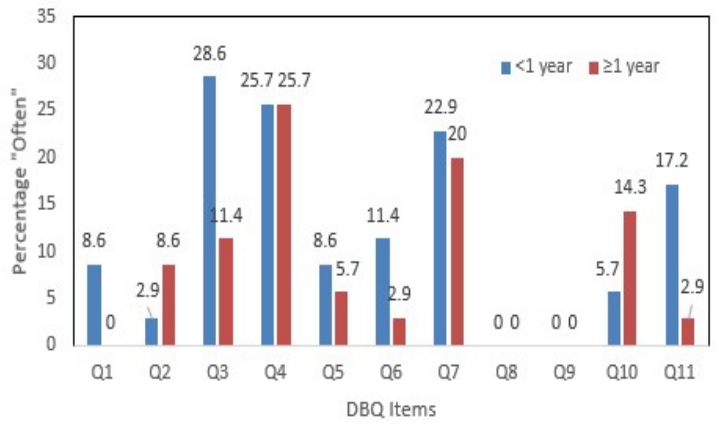

(b)

Figure 2: Comparison of Budapest driver's response "often" based on age and driving experience

\subsubsection{Islamabad sample}

For Islamabad city, the DBQ results showed that specified driver groups based on age and driving experience are more likely to involve in risky driver behavior factors as compared to Budapest drivers. The analysis results showed that drivers with age group '18-21 year' selected the option "often" with high percentage $(\geq 50 \%)$ for most of driver behavior factors such as 'failing to use personal intelligent assistant' (74.3\%), 'failing to yield pedestrian' $(74.3 \%)$, 'frequently changing lanes' $(54.3 \%)$ and 'sounds horn in annoyance' $(60 \%)$. The previous study depicted that the intelligent transport system is helping to change the safety focus from minimizing the consequences of crashes (Khorasani et al., 2013). While the drivers with age group '22-25 year' selected the option 
"often" with high percentage ( $\geq 50 \%)$ for driver behavior factors such as 'failing to use personal intelligent assistant' (62.8\%) and 'failing to yield pedestrian' (54.3\%).

In case of driving experience, the drivers in Islamabad with driving experience less than one year $(<1$ year) are more likely to involve in risky driver behavior factors as compared to drivers with equal to or greater than one year driving experience ( $\geq 1$ year). Accordingly, the drivers with driving experience less than one year selected the option "often" with high percentage $(\geq 50 \%)$ for driver behavior factors such as "failing to comply with traffic light signal' (54.3\%), 'disregard speed limit' $(51.5 \%)$, 'failing to use personal intelligent assistant' $(71.4 \%)$, 'failing to yield pedestrian' $(80 \%)$, 'frequently changing lanes' (51.4\%) and 'sounds horn in annoyance' $(65.7 \%)$. The previous study observed that one of the possible causes for the high number of crashes and injuries is due to beating traffic lights (Subramaniam et al., 2007). While the drivers with driving experience equal to or greater than one year selected the option "often" with high the percentage $(>50 \%)$ for only one driver behavior factor such as 'failing to use personal intelligent assistant' (65.7\%) as shown in Table 4.

Table 4: Descriptive analysis results for Islamabad drivers

\begin{tabular}{|c|c|c|c|c|c|}
\hline \multirow[t]{2}{*}{ Driver behavior factors } & \multirow[t]{2}{*}{ Options } & \multicolumn{2}{|c|}{$\begin{array}{l}\text { Drivers Age } \\
\text { Frequency (\%) }\end{array}$} & \multicolumn{2}{|c|}{$\begin{array}{l}\text { Driving Experience } \\
\text { Frequency }(\%)\end{array}$} \\
\hline & & $\begin{array}{l}18-21 \text { year } \\
(\mathrm{N}=70)\end{array}$ & $\begin{array}{l}21-25 \text { year } \\
(\mathrm{N}=70)\end{array}$ & $\begin{array}{l}<1 \text { year } \\
(\mathrm{N}=70)\end{array}$ & $\begin{array}{l}\geq 1 \text { year } \\
(\mathrm{N}=70)\end{array}$ \\
\hline $\begin{array}{l}\text { Failing to comply with traffic } \\
\text { light signal (Q1) }\end{array}$ & $\begin{array}{l}\text { 1)Often } \\
\text { 2)Sometimes } \\
\text { 3)Never }\end{array}$ & $\begin{array}{l}34(48.6) \\
30(42.8) \\
6(8.6)\end{array}$ & $\begin{array}{l}12(17.2) \\
22(31.4) \\
36(51.4) \\
\end{array}$ & $\begin{array}{l}38(54.3) \\
28(40) \\
4(5.7) \\
\end{array}$ & $\begin{array}{l}8(11.4) \\
24(34.3) \\
38(54.3)\end{array}$ \\
\hline Failing to wear seat belt (Q2) & $\begin{array}{l}\text { 1)Often } \\
\text { 2)Sometimes } \\
\text { 3)Never }\end{array}$ & $\begin{array}{l}26(37.1) \\
38(54.3) \\
6(8.6) \\
\end{array}$ & $\begin{array}{l}21(30.0) \\
32(45.7) \\
17(24.3) \\
\end{array}$ & $\begin{array}{l}28(40) \\
30(42.9) \\
12(17.1) \\
\end{array}$ & $\begin{array}{l}18(25.7) \\
40(57.2) \\
12(17.1) \\
\end{array}$ \\
\hline Disregard speed limit (Q3) & $\begin{array}{l}\text { 1)Often } \\
\text { 2)Sometimes } \\
\text { 3)Never }\end{array}$ & $\begin{array}{l}32(45.7) \\
34(48.6) \\
4(5.7)\end{array}$ & $\begin{array}{l}18(25.7) \\
30(42.9) \\
22(31.4)\end{array}$ & $\begin{array}{l}36(51.5) \\
26(37.1) \\
8(11.4)\end{array}$ & $\begin{array}{l}14(20) \\
38(54.3) \\
18(25.7)\end{array}$ \\
\hline $\begin{array}{l}\text { Failing to use personal } \\
\text { intelligent assistant (Q4) }\end{array}$ & $\begin{array}{l}\text { 1)Often } \\
\text { 2)Sometimes } \\
\text { 3)Never }\end{array}$ & $\begin{array}{l}52(74.3) \\
12(17.1) \\
6(8.6) \\
\end{array}$ & $\begin{array}{l}44(62.8) \\
10(14.3) \\
16(22.9) \\
\end{array}$ & $\begin{array}{l}50(71.4) \\
18(25.7) \\
2(2.9) \\
\end{array}$ & $\begin{array}{l}46(65.7) \\
4(5.7) \\
20(28.6)\end{array}$ \\
\hline $\begin{array}{l}\text { Failing to yield pedestrian } \\
\text { (Q5) }\end{array}$ & $\begin{array}{l}\text { 1)Often } \\
\text { 2)Sometimes } \\
\text { 3)Never }\end{array}$ & $\begin{array}{l}52(74.3) \\
8(11.4) \\
10(14.3)\end{array}$ & $\begin{array}{l}38(54.3) \\
18(25.7) \\
14(20)\end{array}$ & $\begin{array}{l}56(80) \\
10(14.3) \\
4(5.7)\end{array}$ & $\begin{array}{l}34(48.6) \\
16(22.8) \\
20(28.6)\end{array}$ \\
\hline Driving too closely (Q6) & $\begin{array}{l}\text { 1)Often } \\
\text { 2)Sometimes } \\
\text { 3)Never }\end{array}$ & $\begin{array}{l}28(40) \\
34(48.6) \\
8(11.4) \\
\end{array}$ & $\begin{array}{l}9(12.9) \\
25(35.7) \\
36(51.4) \\
\end{array}$ & $\begin{array}{l}33(47.1) \\
28(40) \\
9(12.9) \\
\end{array}$ & $\begin{array}{l}4(5.7) \\
30(42.9) \\
36(51.4) \\
\end{array}$ \\
\hline $\begin{array}{l}\text { Frequently changing lanes } \\
\text { (Q7) }\end{array}$ & $\begin{array}{l}\text { 1)Often } \\
\text { 2)Sometimes } \\
\text { 3)Never }\end{array}$ & $\begin{array}{l}38(54.3) \\
24(34.3) \\
8(11.4) \\
\end{array}$ & $\begin{array}{l}26(37.1) \\
24(34.3) \\
20(28.6) \\
\end{array}$ & $\begin{array}{l}36(51.4) \\
30(42.9) \\
4(5.7) \\
\end{array}$ & $\begin{array}{l}28(40) \\
18(25.7) \\
24(34.3) \\
\end{array}$ \\
\hline $\begin{array}{l}\text { Risk due to encroachments } \\
\text { (Q8) }\end{array}$ & $\begin{array}{l}\text { 1)Often } \\
\text { 2)Sometimes } \\
\text { 3)Never }\end{array}$ & $\begin{array}{l}4(5.7) \\
36(51.4) \\
30(42.9)\end{array}$ & $\begin{array}{l}5(7.1) \\
27(38.6) \\
38(54.3) \\
\end{array}$ & $\begin{array}{l}2(2.9) \\
28(40) \\
40(57.1)\end{array}$ & $\begin{array}{l}8(11.4) \\
34(48.6) \\
28(40)\end{array}$ \\
\hline $\begin{array}{l}\text { Failing to apply brakes in road } \\
\text { hazards (Q9) }\end{array}$ & $\begin{array}{l}\text { 1)Often } \\
\text { 2)Sometimes } \\
\text { 3)Never }\end{array}$ & $\begin{array}{l}12(17.1) \\
34(48.6) \\
24(34.3) \\
\end{array}$ & $\begin{array}{l}4(5.7) \\
14(20) \\
52(74.3)\end{array}$ & $\begin{array}{l}14(20) \\
38(54.3) \\
18(25.7)\end{array}$ & $\begin{array}{l}2(2.9) \\
10(14.3) \\
58(82.8)\end{array}$ \\
\hline $\begin{array}{l}\text { Problems of mixed traffic } \\
\text { (Q10) }\end{array}$ & $\begin{array}{l}\text { 1)Often } \\
\text { 2)Sometimes } \\
\text { 3)Never }\end{array}$ & $\begin{array}{l}17(24.3) \\
33(47.1) \\
20(28.6) \\
\end{array}$ & $\begin{array}{l}22(31.4) \\
36(51.4) \\
12(17.2) \\
\end{array}$ & $\begin{array}{l}20(28.6) \\
26(37.1) \\
24(34.3) \\
\end{array}$ & $\begin{array}{l}21(30.0) \\
42(60) \\
7(10.0)\end{array}$ \\
\hline
\end{tabular}




\begin{tabular}{|l|l|l|l|l|l|}
\hline Sounds horn in annoyance & 1)Often & $42(60)$ & $24(34.3)$ & $46(65.7)$ & $20(28.6)$ \\
(Q11) & 2)Sometimes & $24(34.3)$ & $22(31.4)$ & $14(20)$ & $32(45.7)$ \\
& 3)Never & $4(5.7)$ & $24(34.3)$ & $10(14.3)$ & $18(25.7)$ \\
\hline
\end{tabular}

For Islamabad city, a comparison chart was first developed based on the driver's response "often" for driver age groups '18-21 year' and '22-25 year' as shown in Figure 3 (a). Results showed that drivers with age group '18-21 year' selected the highest percentage "often" for two DBQ items such as 'failing to use personal intelligent assistant' (Q4) and 'failing to yield pedestrian' (Q5). Furthermore, drivers with age group '22-25 year' selected the high percentage "often" for two DBQ items such as 'risk due to encroachments' (Q8) and 'problems of mixed traffic' (Q10) as compared to second evaluator group. Secondly, a comparison chart was developed based on the percentage of option "often" for two driving experience groups ( $<1$ year and $\geq 1$ year) as shown in Figure 3 (b). Results showed the highest percentage "often" for DBQ item such as "failing to yield pedestrian' (Q5) for drivers having driving experience less than one year. While, drivers with high driving experience ( $\geq 1$ year) have high percentage "often" for only one DBQ item such as 'risk due to encroachments' (Q8) as compared to second evaluator group.

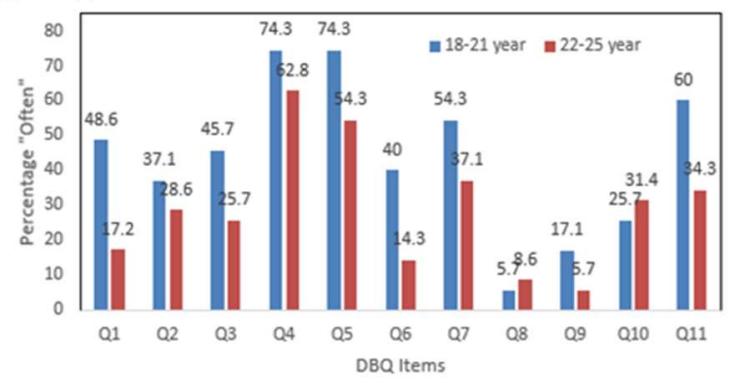

(a)

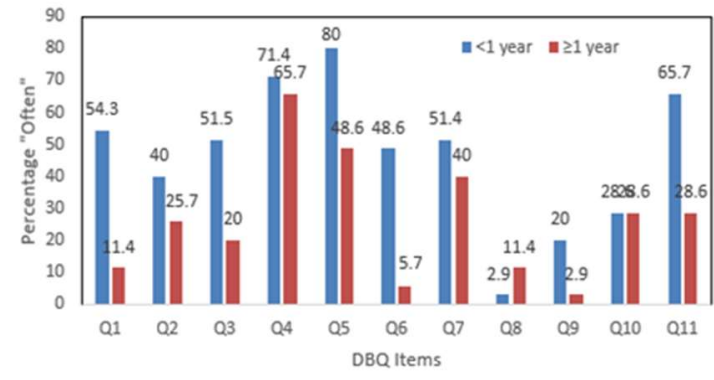

(b)

Figure 3: Comparison of Islamabad driver's response "often" based on age and driving experience

\subsection{ANOVA analysis results}

The analysis of variance (ANOVA) was run to check whether there were significant differences between specified driver groups on DBQ items for Budapest and Islamabad. There are two limits to check the significance of items in the model which are: The Fvalues should be greater than F-critical, and P-value should be less than the significance level. This model considers the significance level of 0.05 .

\subsubsection{Budapest sample}

For Budapest drivers in case of age groups (18-21 year and 22-25 year), the ANOVA results indicated that five items in DBQ sample are statistically significant due to their Fvalues greater than F-critical and P-values less than significance level. While six items are observed statistically non-significant with F-value less then F-critical and P-value greater than 0.05 . The highest F-value is observed for the factor 'failing to yield pedestrian' which shows its high significance. The ANOVA analysis results based on age groups for Budapest drivers are shown in Table 5. 
Table 5: ANOVA analysis results based on drivers age for Budapest city

\begin{tabular}{llllll}
\hline Questionnaire Items & $D F$ & $M S$ & $F$ & $P$-value & F-critical \\
\hline $\begin{array}{l}\text { Failing to comply with traffic } \\
\text { light signal }\end{array}$ & 1 & 0.514 & 1.854 & 0.177 & 3.981 \\
Failing to wear seat belt & 1 & 0.228 & 0.68 & 0.412 & 3.981 \\
$\begin{array}{l}\text { Disregard speed limit } \\
\text { Failing to use personal intelligent }\end{array}$ & 1 & 2.057 & 5.856 & 0.018 & 3.981 \\
assistant & 1 & 0.057 & 0.122 & 0.727 & 3.981 \\
Failing to yield pedestrian & 1 & 2.8 & 8.288 & 0.005 & 3.981 \\
Driving too closely & 1 & 0.514 & 1.471 & 0.229 & 3.981 \\
Frequently changing lanes & 1 & 2.057 & 5.898 & 0.017 & 3.981 \\
Risk due to encroachments & 1 & 0.128 & 0.75 & 0.389 & 3.981 \\
Failing to apply brakes in road & & & & & \\
hazards & 1 & 1.157 & 5.275 & 0.024 & 3.981 \\
Problems of mixed traffic & 1 & 0.357 & 0.803 & 0.373 & 3.981 \\
Sounds horn in annoyance & 1 & 2.8 & 6.664 & 0.011 & 3.981 \\
\hline
\end{tabular}

For Budapest drivers in case of driving experience groups ( $<1$ year and $\geq 1$ year), the ANOVA analysis results showed that five items in DBQ are statistically significant such as 'failing to comply with traffic light signal', 'driving too closely', 'failing to apply brakes in road hazards', 'problems of mixed traffic' and 'sounds horn in annoyance'. These items have F-values greater than F-critical and P-values less than 0.05 . The highest F-value is observed for the factor 'driving too closely'. However, the results observed that six items in DBQ are statistically non-significant as shown in Table 6.

Table 6: ANOVA analysis results based on driving experience for Budapest city

\begin{tabular}{llllll}
\hline Questionnaire Items & $D F$ & $M S$ & $F$ & $P$-value & F-critical \\
\hline $\begin{array}{l}\text { Failing to comply with traffic } \\
\text { light signal }\end{array}$ & 1 & 2.057 & 8.079 & 0.005 & 3.981 \\
Failing to wear seat belt & 1 & 0.228 & 0.68 & 0.412 & 3.981 \\
Disregard speed limit & 1 & 0.914 & 2.484 & 0.119 & 3.981 \\
$\begin{array}{l}\text { Failing to use personal intelligent } \\
\text { assistant }\end{array}$ & 1 & 0.514 & 1.118 & 0.293 & 3.981 \\
Failing to yield pedestrian & 1 & 0.514 & 1.384 & 0.243 & 3.981 \\
Driving too closely & 1 & 3.657 & 12.055 & 0.000 & 3.981 \\
Frequently changing lanes & 1 & 0.228 & 0.608 & 0.438 & 3.981 \\
Risk due to encroachments & 1 & 0.357 & 2.125 & 0.149 & 3.981 \\
Failing to apply brakes in road & & & & & \\
hazards & 1 & 2.414 & 12.020 & 0.000 & 3.981 \\
Problems of mixed traffic & 1 & 2.414 & 5.827 & 0.018 & 3.981 \\
Sounds horn in annoyance & 1 & 2.914 & 9.224 & 0.000 & 3.981 \\
\hline
\end{tabular}

\subsubsection{Islamabad sample}

For Islamabad drivers in case of age groups, the ANOVA analysis results showed that five items in DBQ are statistically significant such as 'failing to comply with traffic light signal', 'disregard speed limit', 'driving too closely', 'failing to apply brakes in road 
hazards' and 'sounds horn in annoyance'. The highest F-value is observed for the factor 'failing to comply with traffic light signal' which shows its high importance. While six items are observed statistically non-significant due to F-value less than F-critical and $\mathrm{P}$ value greater than the significance level (0.05) as shown in Table 7.

Table 7: ANOVA analysis results based on drivers age for Islamabad city

\begin{tabular}{llllll}
\hline Questionnaire Items & $D F$ & $M S$ & $F$ & $P$-value & F-critical \\
\hline $\begin{array}{l}\text { Failing to comply with traffic } \\
\text { light signal }\end{array}$ & 1 & 9.657 & 19.153 & 0.000 & 3.981 \\
Failing to wear seat belt & 1 & 1.157 & 2.450 & 0.122 & 3.981 \\
Disregard speed limit & 1 & 3.214 & 6.549 & 0.012 & 3.981 \\
$\begin{array}{l}\text { Failing to use personal } \\
\text { intelligent assistant }\end{array}$ & 1 & 1.157 & 2.055 & 0.156 & 3.981 \\
Failing to yield pedestrian & 1 & 1.157 & 1.953 & 0.166 & 3.981 \\
Driving too closely & 1 & 7.557 & 15.425 & 0.000 & 3.981 \\
Frequently changing lanes & 1 & 2.057 & 3.558 & 0.063 & 3.981 \\
Risk due to encroachments & 1 & 0.128 & 0.325 & 0.570 & 3.981 \\
Failing to apply brakes in & & & & & \\
road hazards & 1 & 4.628 & 11.038 & 0.001 & 3.981 \\
Problems of mixed traffic & 1 & 0.514 & 0.991 & 0.322 & 3.981 \\
Sounds horn in annoyance & 1 & 5.157 & 9.559 & 0.002 & 3.981 \\
\hline
\end{tabular}

For Islamabad drivers in case of driving experience groups ( $<1$ year and $\geq 1$ year), the ANOVA analysis results showed that most items in DBQ are statistically significant because of F-value greater than F-critical and P-value less than 0.05. The highest F-value is observed for the factor 'failing to comply with traffic light signal'. While only three items in the sample are observed statistically non-significant such as 'failing to wear seat belt', 'risk due to encroachments' and 'problems of mixed traffic' as shown in Table 8.

Table 8: ANOVA analysis results based on driving experience for Islamabad city

\begin{tabular}{llllll}
\hline Questionnaire Items & $D F$ & $M S$ & $F$ & $P$-value & F-critical \\
\hline $\begin{array}{l}\text { Failing to comply with } \\
\text { traffic light signal }\end{array}$ & 1 & 13.728 & 31.9082 & 0.000 & 3.981 \\
Failing to wear seat belt & 1 & 0.357 & 0.737 & 0.393 & 3.981 \\
Disregard speed limit & 1 & 3.657 & 7.702 & 0.007 & 3.981 \\
$\begin{array}{l}\text { Failing to use personal } \\
\text { intelligent assistant }\end{array}$ & 1 & 2.414 & 4.709 & 0.033 & 3.981 \\
Failing to yield pedestrian & 1 & 5.157 & 9.664 & 0.002 & 3.981 \\
Driving too closely & 1 & 12.014 & 28.310 & 0.000 & 3.981 \\
Frequently changing lanes & 1 & 2.8 & 4.936 & 0.029 & 3.981 \\
Risk due to encroachments & 1 & 1.157 & 3.046 & 0.085 & 3.981 \\
Failing to apply brakes in & & & & & \\
road hazards & 1 & 9.657 & 27.961 & 0.000 & 3.981 \\
Problems of mixed traffic & 1 & 0.914 & 1.783 & 0.186 & 3.981 \\
Sounds horn in annoyance & 1 & 4.128 & 7.443 & 0.008 & 3.981 \\
\hline
\end{tabular}




\subsection{Relative risk analysis results}

The relative risk (RR) and the corresponding 100(1- $\alpha) \%$ confidence interval was measured for each risky driver behavior factor in the sample by comparing two driver age groups (18-21 year and 22-25 year) and two driving experience groups $(<1$ year) and $(\geq$ 1 year) for Budapest and Islamabad.

Accordingly, the RR procedure first considered that how much times the drivers age group '18-21 year' is more likely to involve in risky driver behavior factors as compared to the drivers age group '22-25 year'. The RR analysis results showed the value larger than 1 (positive association) for some specified driver behavior factors which shows a high risky attitude of drivers age group '18-21 year' as compared to driver age group '2225 year' year. However, for the few risky driver behavior factors, the RR value was observed smaller than 1 which means negative association. Furthermore, for two risky driver behavior factors, the RR value was observed zero which means no association. Moreover, the $95 \%$ confidence interval values showed that observed RR is statistically significant for most driver behavior factors because these exclude 1.0. For two specified items, the $95 \%$ confidence interval value was observed zero which implies that there is no evidence of risk for road safety as shown in Table 9.

Table 9: Relative risk results based on drivers age groups for Budapest

\begin{tabular}{|c|c|c|c|c|c|}
\hline DBQ Items & Options & $18-21$ & $22-25$ & $\begin{array}{l}\text { Relative } \\
\text { risk }\end{array}$ & $\begin{array}{l}\text { 95\% confidence } \\
\text { interval } \\
\text { (Lower-upper) }\end{array}$ \\
\hline $\begin{array}{l}\text { Failing to comply with } \\
\text { traffic light signal }\end{array}$ & $\begin{array}{l}\text { Often } \\
\text { Never }\end{array}$ & $\begin{array}{l}04 \\
50\end{array}$ & $\begin{array}{l}02 \\
60\end{array}$ & 2.29 & $0.43-12.04$ \\
\hline Failing to wear seat belt & $\begin{array}{l}\text { Often } \\
\text { Never }\end{array}$ & $\begin{array}{l}03 \\
48\end{array}$ & $\begin{array}{l}04 \\
56\end{array}$ & 0.88 & $0.20-3.76$ \\
\hline Disregard speed limit & $\begin{array}{l}\text { Often } \\
\text { Never }\end{array}$ & $\begin{array}{l}18 \\
04\end{array}$ & $\begin{array}{l}10 \\
20\end{array}$ & 2.45 & $1.42-4.22$ \\
\hline $\begin{array}{l}\text { Failing to use personal } \\
\text { intelligent assistant }\end{array}$ & $\begin{array}{l}\text { Often } \\
\text { Never }\end{array}$ & $\begin{array}{l}16 \\
14\end{array}$ & $\begin{array}{l}20 \\
14\end{array}$ & 0.9 & $0.58-1.54$ \\
\hline Failing to yield pedestrian & $\begin{array}{l}\text { Often } \\
\text { Never }\end{array}$ & $\begin{array}{l}08 \\
40\end{array}$ & $\begin{array}{l}02 \\
62 \\
\end{array}$ & 5.3 & $1.18-23.98$ \\
\hline Driving too closely & $\begin{array}{l}\text { Often } \\
\text { Never }\end{array}$ & $\begin{array}{l}05 \\
21\end{array}$ & $\begin{array}{l}04 \\
30\end{array}$ & 1.63 & $0.48-5.49$ \\
\hline Frequently changing lanes & $\begin{array}{l}\text { Often } \\
\text { Never }\end{array}$ & $\begin{array}{l}18 \\
02\end{array}$ & $\begin{array}{l}12 \\
20\end{array}$ & 2.4 & $1.5-3.84$ \\
\hline Risk due to encroachments & $\begin{array}{l}\text { Often } \\
\text { Never }\end{array}$ & $\begin{array}{l}0 \\
52 \\
\end{array}$ & $\begin{array}{l}0 \\
58\end{array}$ & 0 & 0 \\
\hline Failing to apply brakes & $\begin{array}{l}\text { Often } \\
\text { Never }\end{array}$ & $\begin{array}{l}0 \\
36 \\
\end{array}$ & $\begin{array}{l}0 \\
54\end{array}$ & 0 & 0 \\
\hline Problems of mixed traffic & $\begin{array}{l}\text { Often } \\
\text { Never }\end{array}$ & $\begin{array}{l}06 \\
38\end{array}$ & $\begin{array}{l}08 \\
30\end{array}$ & 0.64 & $0.24-1.7$ \\
\hline Sounds horn in annoyance & $\begin{array}{l}\text { Often } \\
\text { Never }\end{array}$ & $\begin{array}{l}11 \\
27 \\
\end{array}$ & $\begin{array}{l}04 \\
30 \\
\end{array}$ & 2.46 & $0.86-7.00$ \\
\hline
\end{tabular}


After that, the RR procedure measured that how much times the driving experience group ( $<1$ year) are more likely to involve in risky driver behavior factors as compared to other driving experience group ( $\geq 1$ year). The RR analysis results showed the value larger than 1 for some specified driver behavior factors which shows a high risky attitude of driving experience group ( $<1$ year) for road safety as compared to other driving experience group ( $\geq 1$ year). However, for the few risky driver behavior factors, the RR value was observed smaller than 1 which means negative association. Furthermore, for two risky driver behavior factors, the RR value was observed zero which means no association. Moreover, the $95 \%$ confidence interval values showed that observed RR is statistically significant for most driver behavior factors because these exclude 1.0. For three specified items, the $95 \%$ confidence interval value was observed zero which implies that there is no evidence of risk for road safety as shown in Table 10.

Table 10: Relative risk results based on driving experience groups for Budapest

\begin{tabular}{|l|l|l|l|l|l|}
\hline DBQ Items & Options & $<1$ year & $\geq 1$ year & $\begin{array}{l}\text { Relative } \\
\text { risk }\end{array}$ & $\begin{array}{l}\text { 95\% confidence } \\
\text { interval } \\
\text { (Lower-upper) }\end{array}$ \\
\hline $\begin{array}{l}\text { Failing to comply with } \\
\text { traffic light signal }\end{array}$ & $\begin{array}{l}\text { Often } \\
\text { Never }\end{array}$ & $\begin{array}{l}6 \\
0\end{array}$ & $\begin{array}{l}46 \\
64\end{array}$ & 0.13 & 0 \\
\hline Failing to wear seat belt & $\begin{array}{l}\text { Often } \\
\text { Never }\end{array}$ & $\begin{array}{l}2 \\
53\end{array}$ & $\begin{array}{l}5 \\
51\end{array}$ & 0.56 & $0.17-1.83$ \\
\hline Disregard speed limit & $\begin{array}{l}\text { Often } \\
\text { Never }\end{array}$ & $\begin{array}{l}20 \\
8\end{array}$ & 10 & 1.83 & $0.99-3.36$ \\
\hline $\begin{array}{l}\text { Failing to use personal } \\
\text { intelligent assistant }\end{array}$ & $\begin{array}{l}\text { Often } \\
\text { Never }\end{array}$ & 18 & 18 & 1.75 & $0.89-3.42$ \\
\hline Failing to yield pedestrian & $\begin{array}{l}\text { Often } \\
\text { Never }\end{array}$ & $\begin{array}{l}6 \\
46\end{array}$ & $\begin{array}{l}4 \\
56\end{array}$ & 1.33 & $0.76-2.30$ \\
\hline Driving too closely & $\begin{array}{l}\text { Often } \\
\text { Never }\end{array}$ & 8 & 3 & 3.03 & $1.64-5.58$ \\
\hline Frequently changing lanes & $\begin{array}{l}\text { Often } \\
\text { Never }\end{array}$ & $\begin{array}{l}12 \\
8\end{array}$ & 14 & 1.46 & $0.76-2.79$ \\
\hline Risk due to encroachments & $\begin{array}{l}\text { Often } \\
\text { Never }\end{array}$ & 0 & 0 & 0 & 0 \\
\hline Failing to apply brakes & $\begin{array}{l}\text { Often } \\
\text { Never }\end{array}$ & 0 & 0 & 0 & 0 \\
\hline Problems of mixed traffic & $\begin{array}{l}\text { Often } \\
\text { Never }\end{array}$ & 4 & 10 & 0.44 & $0.18-1.02$ \\
\hline Sounds horn in annoyance & $\begin{array}{l}\text { Often } \\
\text { Never }\end{array}$ & 12 & 24 & 3.14 & $2.05-4.79$ \\
\hline
\end{tabular}

Finally, the relative risk and the corresponding 100(1- $\alpha) \%$ confidence interval was measured for observed risky driver behavior factors in the sample by comparing two driver age groups (18-21 year and 22-25 year) and two driving experience groups $(<1$ year and $\geq 1$ year) for Islamabad.

The RR analysis results showed the value larger than 1 for most specified driver behavior factors which shows a high risky attitude of drivers age group '18-21 year' for road safety as compared to driver age group '22-25 year'. However, for one driver 
behavior factor 'risk due to encroachments', the RR value was observed equal to 1 which means no association. Furthermore, for one driver behavior factor 'problems of mixed traffic', the RR value was observed less than 1 which means negative association. Moreover, the $95 \%$ confidence interval values showed that observed RR is statistically significant for most driver behavior factors except one driver behavior factor 'risk due to encroachments' for which the observed RR is not statistically significantly as its value differ from 1.0 as shown in Table 11.

Table 11: Relative risk results based on drivers age groups for Islamabad

\begin{tabular}{|c|c|c|c|c|c|}
\hline DBQ Items & Options & $18-21$ & $22-25$ & $\begin{array}{l}\text { Relative } \\
\text { risk }\end{array}$ & $\begin{array}{l}\text { 95\% confidence } \\
\text { interval } \\
\text { (Lower-upper) }\end{array}$ \\
\hline $\begin{array}{l}\text { Failing to comply with } \\
\text { traffic light signal }\end{array}$ & $\begin{array}{l}\text { Often } \\
\text { Never }\end{array}$ & $\begin{array}{l}34 \\
6\end{array}$ & $\begin{array}{l}12 \\
36\end{array}$ & 5.17 & $2.41-11.06$ \\
\hline Failing to wear seat belt & $\begin{array}{l}\text { Often } \\
\text { Never }\end{array}$ & $\begin{array}{l}26 \\
6\end{array}$ & $\begin{array}{l}21 \\
17\end{array}$ & 2.12 & $1.01-4.41$ \\
\hline Disregard speed limit & $\begin{array}{l}\text { Often } \\
\text { Never }\end{array}$ & $\begin{array}{l}32 \\
4\end{array}$ & $\begin{array}{l}18 \\
22\end{array}$ & 4.16 & $1.64-10.49$ \\
\hline $\begin{array}{l}\text { Failing to use personal } \\
\text { intelligent assistant }\end{array}$ & $\begin{array}{l}\text { Often } \\
\text { Never }\end{array}$ & $\begin{array}{l}52 \\
6\end{array}$ & $\begin{array}{l}44 \\
16\end{array}$ & 1.98 & $0.97-4.02$ \\
\hline Failing to yield pedestrian & $\begin{array}{l}\text { Often } \\
\text { Never }\end{array}$ & $\begin{array}{l}52 \\
10\end{array}$ & $\begin{array}{l}38 \\
14\end{array}$ & 1.38 & $0.83-2.29$ \\
\hline Driving too closely & $\begin{array}{l}\text { Often } \\
\text { Never }\end{array}$ & $\begin{array}{l}28 \\
8\end{array}$ & $\begin{array}{l}9 \\
36\end{array}$ & 4.16 & $2.16-7.99$ \\
\hline Frequently changing lanes & $\begin{array}{l}\text { Often } \\
\text { Never }\end{array}$ & $\begin{array}{l}38 \\
8\end{array}$ & $\begin{array}{l}26 \\
20\end{array}$ & 2.07 & $1.11-3.86$ \\
\hline Risk due to encroachments & $\begin{array}{l}\text { Often } \\
\text { Never }\end{array}$ & $\begin{array}{l}4 \\
30\end{array}$ & $\begin{array}{l}5 \\
38 \\
\end{array}$ & 1 & $0.46-2.19$ \\
\hline Failing to apply brakes & $\begin{array}{l}\text { Often } \\
\text { Never }\end{array}$ & $\begin{array}{l}12 \\
24\end{array}$ & $\begin{array}{l}4 \\
52\end{array}$ & 2.37 & $1.53-3.67$ \\
\hline Problems of mixed traffic & $\begin{array}{l}\text { Often } \\
\text { Never }\end{array}$ & $\begin{array}{l}17 \\
20\end{array}$ & $\begin{array}{l}22 \\
12\end{array}$ & 0.69 & $0.44-1.09$ \\
\hline Sounds horn in annoyance & $\begin{array}{l}\text { Often } \\
\text { Never }\end{array}$ & $\begin{array}{l}42 \\
4\end{array}$ & $\begin{array}{l}24 \\
24\end{array}$ & 4.45 & $1.76-11.23$ \\
\hline
\end{tabular}

Moreover, the RR analysis results showed the value larger than 1 for most specified driver behavior factors which shows a high risky attitude of driving experience group $(<$ 1 year) as compared to the other driving experience group ( $\geq 1$ year). However, for the two driver behavior factors 'risk due to encroachments' and 'problems of mixed traffic', the RR value was observed less than 1 which means negative association. Moreover, the $95 \%$ confidence interval values showed that observed RR is statistically significant for most driver behavior factors except one driver behavior factor 'problems of mixed traffic' for which the observed RR is not statistically significantly as its value differ from 1.0 as shown in Table 12. 
Table 12: Relative risk based on driving experience groups for Islamabad

\begin{tabular}{|c|c|c|c|c|c|}
\hline DBQ Items & Options & $<1$ year & $\geq 1$ year & $\begin{array}{l}\text { Relative } \\
\text { risk }\end{array}$ & $\begin{array}{l}95 \% \text { confidence } \\
\text { interval } \\
\text { (Lower-upper) }\end{array}$ \\
\hline $\begin{array}{l}\text { Failing to comply with } \\
\text { traffic light signal }\end{array}$ & $\begin{array}{l}\text { Often } \\
\text { Never }\end{array}$ & $\begin{array}{l}38 \\
4\end{array}$ & $\begin{array}{l}8 \\
38\end{array}$ & 8.67 & $3.38-22.23$ \\
\hline Failing to wear seat belt & $\begin{array}{l}\text { Often } \\
\text { Never }\end{array}$ & $\begin{array}{l}28 \\
12\end{array}$ & $\begin{array}{l}18 \\
12\end{array}$ & 1.21 & $0.76-1.93$ \\
\hline Disregard speed limit & $\begin{array}{l}\text { Often } \\
\text { Never }\end{array}$ & $\begin{array}{l}36 \\
8\end{array}$ & $\begin{array}{l}14 \\
18\end{array}$ & 2.34 & $1.28-4.27$ \\
\hline $\begin{array}{l}\text { Failing to use personal } \\
\text { intelligent assistant }\end{array}$ & $\begin{array}{l}\text { Often } \\
\text { Never }\end{array}$ & $\begin{array}{l}50 \\
2\end{array}$ & $\begin{array}{l}46 \\
20\end{array}$ & 5.72 & $1.50-21.77$ \\
\hline Failing to yield pedestrian & $\begin{array}{l}\text { Often } \\
\text { Never }\end{array}$ & $\begin{array}{l}56 \\
4 \\
\end{array}$ & $\begin{array}{l}34 \\
20\end{array}$ & 3.73 & $1.50-9.26$ \\
\hline Driving too closely & $\begin{array}{l}\text { Often } \\
\text { Never }\end{array}$ & $\begin{array}{l}33 \\
9\end{array}$ & $\begin{array}{l}4 \\
36 \\
\end{array}$ & 4.45 & $2.45-8.08$ \\
\hline Frequently changing lanes & $\begin{array}{l}\text { Often } \\
\text { Never }\end{array}$ & $\begin{array}{l}36 \\
4\end{array}$ & $\begin{array}{l}28 \\
24\end{array}$ & 3.93 & $1.54-10$ \\
\hline Risk due to encroachments & $\begin{array}{l}\text { Often } \\
\text { Never }\end{array}$ & $\begin{array}{l}2 \\
40\end{array}$ & $\begin{array}{l}8 \\
28\end{array}$ & 0.34 & $0.09-1.19$ \\
\hline Failing to apply brakes & $\begin{array}{l}\text { Often } \\
\text { Never }\end{array}$ & $\begin{array}{l}14 \\
18\end{array}$ & $\begin{array}{l}2 \\
58\end{array}$ & 3.69 & $2.36-5.75$ \\
\hline Problems of mixed traffic & $\begin{array}{l}\text { Often } \\
\text { Never }\end{array}$ & $\begin{array}{l}20 \\
24\end{array}$ & $\begin{array}{l}21 \\
7\end{array}$ & 0.63 & $0.43-0.9$ \\
\hline Sounds horn in annoyance & $\begin{array}{l}\text { Often } \\
\text { Never }\end{array}$ & $\begin{array}{l}46 \\
10 \\
\end{array}$ & $\begin{array}{l}20 \\
18 \\
\end{array}$ & 1.95 & $1.15-3.28$ \\
\hline
\end{tabular}

\section{Conclusion}

The study evaluated and compared the risky driver behavior factors based on age and driving experience for Budapest and Islamabad drivers by utilizing the driver behavior questionnaire (DBQ) as a tool. The DBQ results found significant differences in risky driver behavior factors between observed groups. The drivers with age group ' $18-21$ year' and drivers with driving experience less than one year are more likely to involve in risky driver behavior factors as compared to other studied groups.

This study was comparative in providing the basic analysis of risky driver behavior factors which could involve in traffic accidents while considering drivers age and level of experience for Budapest and Islamabad. The analysis results showed that Islamabad drivers are more concerned in traffic safety issues which can be explained due to increased traffic, uncontrolled traffic, high numbers of motorbikes on the road, reckless driving behavior and unawareness of traffic rules. While Budapest drivers with observed groups are found more discipline in traffic safety due to better traffic planning, traffic control and improved driver behavior. However, the use of intelligent traffic systems such as GPS and driver information system should be improved to enhance the road safety for all driver groups of Budapest and Islamabad. The study results could be a helpful evaluation to highlight the risky driver behavior factors based on age and driving experience for Budapest and Islamabad. The highlighted risky driver behavior factors should be more focused by local policymakers to solve road safety issues. Also, traffic safety campaigns based on mainly the driver's compliance with speed limits, lane- 
changing rules and use of intelligent traffic systems should be held in educational institutes to address the considerations which may lead to improved perceived risk and lower engagement in risky driving behaviors. However, there is a need for more research with the use of naturalistic tools to investigate comprehensively the risky driver behavior factors that influence road safety.

\section{References}

Al Reesi, H., Al Maniri, A., Plankermann, K., Al Hinai, M., Al Adawi, S., Davey, J., Freeman, J. (2013) "Risky driving behavior among university students and staff in the Sultanate of Oman", Accident Analysis and Prevention 58, pp. 1-9.

ADB, (1996) "Road safety guidelines for the Asian and Pacific Region", Manila, Philphine.

Bener, A., Ozkan, T., Lajunen, T. (2008) "The Driver Behavior Questionnaire in Arab Gulf countries: Qatar and United Arab Emirates", Accident Analysis and Prevention 40, pp. 1411-1417.

Bener, A., Crundall, D. (2008) "Effects of driver behavior on accident involvement: The role of gender and driver behavior in Road Traffic Crashes", International Journal of Crashworthiness 13(3), pp. 331-336.

Bilban, M., Zaletel-Kragelj, L. (2007) "Seat-belt use and non-use at adults in Slovenia" International Journal of Public Health 52, pp. 317-325.

BITRE (Bureau of Infrastructure, Transport and Regional Economics). (2014) "Road deaths Australia", 2013 Statistical Summary, Canberra: Department of Infrastructure and Regional Development.

European Commission, (2016) “Annual Accident Report", European Commission, Directorate General for Transport, June 2016.

Chakraborty, A. (2014) "Effects of air pollution on public health: the case of vital traffic junctions under Kolkata Municipal Corporation", Journal of Studies in Dynamics and Change 1(3), 125-133.

Park, E., Cho, M., Ki, C. S. (2009) "Correct Use of Repeated Measures Analysis of Variance", Korean J Lab Med. 29, pp. 1-9.

Farooq, D., Juhasz, J. (2018) "Analysis of Young Driver Behavior related to Road Safety Issues in Pakistan and Hungary', In: Proceedings of the 3rd World Congress on Civil, Structural, and Environmental Engineering (CSEE'18), Budapest, Hungary, Paper No. ICTE 109.

Farooq, D., Moslem, S., Duleba, S. (2019) "Evaluation of Driver Behavior Criteria for Evolution of Sustainable Traffic Safety", Sustainability 11, pp.3142.

Farooq, D., Moslem, S. (2019) "Evaluation and Ranking of Driver Behavior Factors Related to Road Safety by Applying Analytic Network Process", Periodica Polytechnica Transportation Engineering.

Hassan, H. M., Shawkya, M., Kishta, M., Gariba, A. M., Al-Harthei, H. A. (2017) "Investigation of drivers' behavior towards speeds using crash data and self-reported questionnaire", Accident Analysis and Prevention 98, pp. 348-358.

IRTAD, (2011) "Road Safety Annual Report", OECD/ITF.

Iversen, H. (2004) "Risk-taking attitudes and risky driving behavior", Transportation Research Part F 7, pp. 135-150.

Khorasani, G., Tatari, A., Yadollahi, A., Rahimi, M. (2013) "Evaluation of Intelligent Transport System in Road Safety”, Int. J. Chem. Environ. Biol. Sci. (IJCEBS), 1. 
Lajunen, T., Parker, D., Summala, H. (2004) "The Manchester Driver Behavior Questionnaire: a cross-cultural study", Accident Analysis and Prevention 42, pp. 1-8.

Lord, D., Washington, S. P., Ivan, J. N., Poisson. (2005) "Poisson-gamma and zeroinflated regression models of motor vehicle crashes: balancing statistical fit and theory", Accident Analysis and Prevention 37, pp. 35-46.

Lund, I. O., Rundmo, T. (2009) "Cross-cultural comparisons of traffic safety, risk perception, attitudes and behavior", Safety Science 47(4), pp. 547-553.

Machin, M. A., Sankey, K. S. (2008) "Relationships between young drivers' personality characteristics, risk perceptions, and driving behavior", Accident Analysis \& Prevention 40(2), pp. 541-547.

McEvoy, S. P., Stevenson, M. R., Woodward, M. (2006) "The impact of driver distraction on road safety: results from a representative survey in two Australian states", Traffic Injury Prevention 12(4), pp. 242-247.

NHTSA, (2008) "National Motor Vehicle Crash Causation Survey", U.S Department of Transportation: Washington, DC, USA.

OECD/ITF, (2016) Road Safety Annual Report, OECD: Paris, France, ITF, London, UK.

Ozkan, T., Lajunen, T., Chliaoutakies, J., Parker, D., Summala, H. (2006) "Cross cultural differences on driving behaviors: a comparison of 6 countries", Transportation Research Part F 9, pp. 227-242.

Papaioannou, P. (2007) "Driver behavior, dilemma zone and safety effects at urban signalised intersections in Greece", Accident Analysis and Prevention 39, pp. 147-158.

Parker, D., Reason, J. T., Manstead, A. S. R., Stradling, S. G. (1995) "Driving errors, driving violations and accident involvement", Ergonomics 38, pp. 1036-1048.

Reason, J. T., Manstead, A. S. R., Stradling, S., Baxter, J., Campbell, K. (1990) "Errors and violations on the roads", Ergonomics 33, pp. 1315-1332.

Salvatore L., Natalia D, Giulia P. (2019) "Multiple Correspondence Analysis (MCA) for the evaluation of risk perception of roundabouts for young people", European Transport Issue 72, Paper $\mathrm{n}^{\circ} 4$.

Statistics Solutions. Advancement through clarity. https://www.statisticssolutions.com/relative-risk/. [Accessed: 10 July 2020].

Subramaniam, K., Phang, W. K., Hayati, K. S. (2007) "Traffic light violation among motorists in Malaysia", IATSS 31, pp. 67-73.

Talbot, R., Aigner-Breuss, E., Kaiser, S., Alfonsi, R., Braun, E., and et al., (2016) "Identification of Road User related Risk Factors" Safety Cube Deliverable 4.1. [Research Report] IFSTTAR - Institute Français des Sciences et Technologies des Transports, de l'Aménagement et des Réseaux, 541, 2016.

Takada, M., Takeno, A., Iwamiya, S. (2010) "Effects of vehicle horn acoustic properties on auditory impressions and the interpretation of reasons for horn use by other drivers", Noise Control Engineering Journal 58, pp. 259-272.

Viola, R., Roe, M., Shin, H (2010) "The New York City pedestrian safety study and action plan" New York City Department of Transportation, USA.

Wang, J., Ding, J. X., Shi, Q., Kühne, R. D. (2016) "Lane-changing behavior and its effect on energy dissipation using full velocity difference model" International Journal of Modern Physics C, 27 (2), 1650013.

World Health Organization (WHO), (2013) “Global status report on road safety" Geneva, Switzerland.

World Health Organization (WHO), (2020) "The 3rd Global Ministerial Conference on Road Safety”, Achieving global goals 2030, Stockholm, 19-20 February 2020. 
European Transport $\backslash$ Trasporti Europei (2020) Issue 80, Paper n 2, ISSN 1825-3997

Yanagisawa, M., Swanson, E., Najm, W. G (2014) "Target crashes and safety benefits estimation methodology for pedestrian crash avoidance/mitigation systems", (Report No. DOT HS 811 998), Washington, DC: National Highway Traffic Safety Administration. 